\title{
Nevrorehabilitering - høyspesialisert behandling
}

En tredel av all sykdom rammer hjernen og nervesystemet (1). Det er beregnet at Norge årlig bruker 80 milliarder kroner på slik sykdom (2). Mange hjernesykdommer rammer akutt, kan behandles effektivt og gir ingen senfølger. Andre er kroniske og krever langvarig behandling og oppfølging. Nevrologi kombinerer hyperakutt intervensjonsbehandling med langtidsrehabilitering. Hjernen og nervesystemet har begrenset regenerasjonsevne, og sykdommer kan medføre langvarig funksjonstap og ha et kronisk forløp. Dette gir behov for spesialisert medisinsk oppfølging over tid.

Nevrorehabilitering innebærer tverrfaglig medisinsk behandling for sykdommer i hjernen og nervesystemet. Målet er å sikre optimal funksjon og minst mulig plager. Innsikt og opplæring er et hovedelement i nevrorehabilitering. Flere yrkesgrupper er alltid involvert. Organiseringen og samarbeidet mellom disse og mellom ulike nivåer i helsetjenesten er avgjørende for samlet kvalitet. Pasienten selv vil ofte ha en koordinatorrolle. Nevrolog og fastlege er likeledes sentrale i samordningen.

Trygve Holmøy og medarbeidere har i dette nummer av Tidsskriftet vurdert én type nevrorehabilitering, nemlig effekten av 3-4 ukers opphold ved et spesialisert senter (3). Institusjonen gir tilbud til én diagnosegruppe, multippel sklerose (MS). Det store flertallet av 277 pasienter innlagt i 2010 var godt fornøyd eller svært godt fornøyd med oppholdet. Dette gjaldt både effekt på livskvalitet, psykisk helse og mestring av daglige gjøremål. Undersøkelsen bekrefter tidligere studier, som viser at pasienter og pårørende etterspør rehabilitering, ikke minst relativt kortvarige opphold med trening og veiledning individuelt og i grupper $(4,5)$. Som ved MSSenteret Hakadal kombineres spesialisert medisinsk innsikt med fysio- og ergoterapi, sosionom- og psykologvurdering og kostveiledning. Dialog, sammensatte aktiviteter, definisjon av mål og tiltak under oppholdet og etter utskrivning er sentrale elementer.

Pasienttilfredshet er en viktig parameter i vurderingen av medisinsk behandling, men utgjør ikke alene et tilstrekkelig grunnlag for valg mellom ulike alternativer. I nevrorehabilitering er det en rekke behandlingsvariabler som har betydning for sluttresultatet, noe som gjør systematiske undersøkelser utfordrende. Hvilke elementer i rehabiliteringen er viktige, hvilke mindre viktige, og hvilke spiller ingen rolle? Et typisk eksempel diskutert i Norge har vært betydning av varmt klima for nevrorehabilitering. Pasientene er gjennomgående tilfreds med behandling i varmen i Syden, men myndighetene har satt klare krav til kontrollerte undersøkelser for hver enkelt pasientgruppe. Her kreves det dokumentasjon av langvarig positiv effekt av det spesifikke elementet varmt klima for å gi økonomisk støtte.

Kontrollerte undersøkelser alene kan neppe være det eneste svaret på spørsmålet om aktuelle vurderingsformer for en så kompleks behandling som nevrorehabilitering. Rigorøse krav, slik som i Cochranedatabasen, er nyttige, men kan bli for snevre som en praktisk rettesnor. Målet må imidlertid være at både enkeltelementer og helheten i nevrorehabilitering for definerte pasientgrupper skal vurderes like godt i kontrollerte studier som medikamentell behandling. I praksis har dette vært vanskelig å få til. Retningslinjer for behandling tar derfor i tillegg hensyn til en ekspertvurdering av studier med lavere kvalitet. Kostnad-nytte-betraktninger er sentrale for all medisinsk virksomhet. Spørsmålet er slett ikke bare effekt versus ikke-effekt, men graden av effekt og med hvilke kostnader for pasient, pårørende og samfunn. Nevrorehabilitering oppleves positivt, kan dokumentere nytte, og nytten øker med omfanget og ressurser som settes inn. Men hvordan slik behandling porsjoneres ut til hver enkelt pasient, hvor hyppig og med hvilken oppfølging, bygger mer på tradisjon, erfaring og kvalifisert synsing enn dokumentert viten.

Multippel sklerose kan ramme alle deler av sentralnervesystemet. Symptomene skyldes inflammasjon, demyelinisering og nevrondegenerasjon. Sykdomsmodifiserende og medikamentell intervensjon er i rivende utvikling. Behandling med stamceller er et alternativ for aggressiv sykdom. Spastisitet, epilepsi og andre symptomer krever avansert terapi. Ny teknologi åpner for effektive hjelpemidler. Med 7 000-8 000 norske pasienter er dette ingen liten oppgave. Enheter for behandling av multippel sklerose må være en del av spesialiserte miljøer med kompetanse innen flere felter. Nevrorehabilitering bør drives i samarbeid med institusjoner med tilgang til bred og avansert ekspertise. Nasjonalt kompetansesenter for multippel sklerose ved Haukeland universitetssykehus skal sikre tilstrekkelig god behandling, men behandler ikke enkeltpasienter. Senteret har som oppgave å definere nasjonale standarder, sikre at disse følges, samt stimulere og drive forskning.

Hjernen og hjernens sykdommer utgjør en stor utfordring for pasienter, pårørende, profesjonelle behandlere og samfunnet. Det er flere ulike instanser som arbeider for forskning, behandling og informasjon om hjernesykdommer der pasienten har et langvarig rehabiliteringsbehov. Hjernerådets arbeid og Forskningsrådets program NevroNor er eksempler på dette. I helsemyndighetenes ferske Nevroplan 2015, er rehabilitering, flerfaglig utviklingsarbeid og informasjon med utvikling av ny kunnskap de tre hovedelementene. Multippel sklerose er en av sykdommene som omtales spesielt.

Nevrorehabilitering skal for en stor del foregå lokalt og pasientnært, men den spesialiserte kompetansen er særdeles viktig, slik også erfaringene fra MS-Senteret Hakadal indikerer. I et nasjonalt perspektiv er det utvilsomt fortsatt rom for forbedring i behandlingen og oppfølgingen av pasienter med denne sykdommen.

\section{Nils Erik Gilhus}

nils.gilhus@helse-bergen.no

Nils Erik Gilhus (f. 1950) er professor ved Universitetet i Bergen og overlege i nevrologi ved Haukeland universitetssykehus. Han er leder for Institutt for klinisk medisin, Universitetet i Bergen, leder satsingen NevroNor i Norges forskningsråd og er nestleder i Hjernerådet. Forfatter har fylt ut ICMJE-skjemaet og oppgir ingen interessekonflikter.

\footnotetext{
Litteratur

. Olesen J, Leonardi M. The burden of brain diseases in Europe. Eur J Neurol 2003; 10: 471-7

Gustavsson A Svensson M, Jacobi F et al. Cost of disorders of the brain in Europe 2010. Eur Neuropsychopharmacol 2011; 21: 718-79.

3. Holmøy T, Hanssen KT, Beiske AG. Pasienttilfredshet ved rehabilitering av pasienter med multippel sklerose. Tidsskr Nor Legeforen 2012; 132: 523-5. 4. EFNS Task Force. Standards in neurological rehabilitation. Eur J Neurol 1997; 4: 325-31.

5. Rasova K, Feys P. Henze T et al. Emerging evidence-based physical rehabilitation for multiple sclerosis; towards an inventory of current content across Europe. Health Qual Life Outcomes 2010; 8: 76.
} 